\title{
Effect of qualitative feed restriction on energy metabolism and nitrogen retention in sheep
}

\author{
A. Kamalzadeh ${ }^{1 \#}$, W.J. Koops ${ }^{2}$ and A. Kiasat ${ }^{3}$ \\ ${ }^{1}$ Institute of Scientific-Applied Higher Education of Jihad-e-Agriculture, P.O. Box 13145-783, Tehran, I R Iran \\ ${ }^{2}$ Wageningen Agriculture University, P.O. Box 338, 6700 AH, Wageningen, The Netherlands \\ ${ }^{3}$ Esteghlal High School, Hashemi Ave., Tehran, I R Iran
}

\begin{abstract}
Periodic restrictions in feed quality and quantity is an important phenomenon in regions where animal production should bridge the gap between periods of forage production separated by a dry season. Eighteen Swifter male lambs, weaned at the age of $c a$. three months, were used to quantify effects of feed quality restriction and realimentation on changes in energy and nitrogen metabolism. The diet consisted of grass straw (17 MJ of gross energy [GE] and $46 \mathrm{~g}$ crude protein [CP] per kg dry matter [DM]) on an ad libitum basis and $35 \mathrm{~g} / \mathrm{kg}^{0.75} / \mathrm{d}$ mixed concentrates (16.5 MJ of GE and $173 \mathrm{~g} \mathrm{CP}$ per kg DM). At the age of ca. 3.5 months the animals were randomly divided into six blocks, based on live weight, according to a randomized complete block design. Within each block, the animals were randomly assigned to two restricted treatments (R1 and R2) and an unrestricted control (C) treatment. Treatments R1 and R2 were subjected to feed quality restriction by withholding the concentrate for 3 and 4.5 months, respectively. A modified linear model was developed to study the effects of restriction and realimentation. The comparison between treatments was made by analyzing the data of the R1 and R2 animals as deviations from the control animal in each block. During the restriction period, restricted animals lost weight and showed negative energy (EB) and nitrogen balances (NB), whereas their intake of low quality roughage increased significantly. During the realimentation period ( 5 and 6 months for the R1 and R2 animal, respectively), the R1 and R2 animals grew significantly faster than the control animals. The realimented animals persisted in ingesting significantly more low quality roughage and their EB and NB were significantly greater that those of the control animals. The R2 animals needed a longer period of realimentation because of a longer period of restriction. The expression of compensatory growth was mainly related to a sustained higher grass straw (low quality roughage) intake during the realimentation periods, and a significantly greater efficiency of metabolizable energy intake. The maintenance requirement of realimented animals was significantly lower only during the initial stages of realimentation compared with the controls. It seemed as if a three months feed restriction period in weaned sheep was better than 4.5 months.
\end{abstract}

Keywords: Energy metabolism, feed quality, metabolizability, nitrogen retention, sheep, restriction

\#Corresponding author. E-mail: az_kamalzadeh@yahoo.com

\section{Introduction}

There is an abundance of research results (Ryan et al., 1993; Kamalzadeh et al., 1997; Hoch et al., 2005; Kamalzadeh, 2005) in the field of feed restriction and compensatory growth. In most of the studies the experimental animals were assigned to feed quantity restrictions in which animals were forced to eat a limited amount of feed. On the other hand, published results on the effects of feed quality restriction in sheep is limited. In feed quality restriction, animals always have access to low quality feed. Compensatory growth may be associated with lower maintenance requirements during the recovery period, an increase in the growth efficiency, an increase in feed intake and changes in body composition and the content of the digestive tract. Several reports (Walker \& Garrett, 1970; Graham \& Searle, 1972; Graham et al., 1974; Foot \& Tulloh, 1977; Ledger \& Sayers, 1977; Gray \& McCraken, 1979; Andersen, 1980) have shown that fasting heat production (FHP) or maintenance requirements decreases in response to low levels of feed intake. Other reports (Drew \& Reid, 1975; Webster et al., 1982) indicated that nutritional levels did not influence FHP or maintenance requirements, whilst Ferrel et al. (1986) demonstrated that efficiency of feed utilization and the amount of food required to maintain body weight may be influenced by previous plane of nutrition. In many of these studies, however, the influences of nutritional level, duration of nutritional treatment, age or 
body weight have been confounded. An increase in intake of realimented sheep has been reported in some studies (Winter et al., 1976; Graham \& Searle, 1979; Kamalzadeh et al., 1997). In contrast, Hogg (1977) found no differences in the feed intake between realimented animals and their controls. According to the ARC (1980), the metabolizable energy (ME) required for maintenance in sheep varies between 420 and 450 $\mathrm{kJ} / \mathrm{kg}^{0.75} / \mathrm{d}$, whereas Graham \& Searle (1979) found that sheep subjected to feed restrictions require an ME intake of only $340 \mathrm{~kJ} / \mathrm{kg}^{0.75} / \mathrm{d}$ at zero energy balance (maintenance). After realimentation these reduced maintenance requirements during restriction only persisted at the initial stages of realimentation and temporarily resulted in comparatively more energy for gain. The efficiency of ME for maintenance and growth is related to the ME intake level and metabolizability (ME/gross energy [GE]) of the feed. The efficiency of energy deposition (i.e. net energy) may change during compensatory growth. The efficiency of ME utilization increases with increasing metabolizability of energy (Thomson et al., 1982).

In many parts of the world ruminant production systems are extensive and depend mainly on natural vegetation of range- and farmlands. The effect of low quality forages on animal production is accentuated by seasonal variation. Seasonal variations cause periodic live weight loss and gain in grazing animals. Ruminant production systems often face prolonged dry seasons where available feed cannot meet animal requirements. In most parts of the world the growing season starts with the onset of the rainy season. At the beginning of the growing season the grasses contain on average $90-110 \mathrm{~g}$ crude protein $(\mathrm{CP}) / \mathrm{kg}$, and the digestibility is about $60-65 \%$. These values decrease during the dry season. During a prolonged period of the year the protein content is only $40-50 \mathrm{~g} / \mathrm{kg}$ and the digestibility between 40 and $50 \%$. Kamalzadeh (2005) reported that integration of extensive and intensive systems could increase the productivity of the animals and reduce the damage to the environment. The present study was designed to evaluate the effects of feed quality restriction on energy metabolism and nitrogen $(\mathrm{N})$ retention in immature sheep, and to study the expression of compensatory growth in relation to changes in feed intake, maintenance energy requirements and feed efficiency.

\section{Materials and Methods}

Eighteen crossbred Swifter (Flemish $q$ x Texel $\delta^{\Uparrow}$ ) male lambs were randomly selected from a flock of about 450 head. Average birth weight was $4 \pm 0.25 \mathrm{~kg}$ and average live weight at weaning (ca. three months of age) was $30 \pm 0.64 \mathrm{~kg}$. The experiment started when the lambs were ca.3.5 months old with an average live weight of $c a .34 \pm 0.72 \mathrm{~kg}$. Animals were allocated to six blocks, each containing three nearly identical lambs, based on initial live weight, according to a randomized complete block design. Within each block the animals were then randomly assigned to three treatments: control (C); 3 months period of restriction (R1); and 4.5 months period of restriction (R2). The control group received a low quality roughage on an ad libitum basis and a concentrate supplement. For a period of three months the R1 animals and, for a period of 4.5 months, the R2 animals were allowed to consume only the low quality roughage on an ad libitum basis, plus a mineral supplement $\left(1 \mathrm{~g} / \mathrm{kg}^{0.75} / \mathrm{d}\right)$, but no concentrate. During realimentation the $\mathrm{R} 1$ and $\mathrm{R} 2$ animals received the same diet as the control animals.

The low quality roughage was Festuca arundinacea straw. The grass straw was chopped to reduce selection by animals. The straw contained $17 \mathrm{MJ}$ of GE and $46 \mathrm{~g}$ analyzed $\mathrm{CP} / \mathrm{kg}$ dry matter (DM). To ensure an ad libitum feeding regimen, the animals were fed at a level of $100 \mathrm{~g}$ of grass straw $/ \mathrm{kg}$ metabolic weight/d (twice maintenance). The concentrate contained $16.5 \mathrm{MJ}$ of GE and $173 \mathrm{~g}$ analyzed $\mathrm{CP} / \mathrm{kg} \mathrm{DM}$, and was offered at $35 \mathrm{~g} / \mathrm{kg}^{0.75} / \mathrm{d}$. The composition of the diets is presented in Table 1. The concentrate consisted of a ground and pelleted mixture of sugar beet pulp, potato protein and a mineral mixture of mervit 318 (vitamins A, D and trace elements, $\mathrm{NaH}_{2} \mathrm{PO}_{4} \cdot 2 \mathrm{H}_{2} \mathrm{O}, \mathrm{FeSO}_{4} \cdot 7 \mathrm{H}_{2} \mathrm{O}$ and $\mathrm{MgSO}_{4} \cdot 7 \mathrm{H}_{2} \mathrm{O}$ ) (Table 2). The straw was offered twice a day at 7:00 and 16:00 and the concentrate at 7:30 ad 16:30. At all times the concentrate was consumed completely. Grass straw refusals were collected daily prior to the morning feeding. All lambs were treated with IVOMEC against internal parasites. The environmental temperature was kept constant at $20{ }^{\circ} \mathrm{C}$ and relative humidity was maintained at $c a .70 \%$. The day length during the experiment was set at $12 \mathrm{~h}$, from 7:00 to 19:00.

The duration of the experiment was 10.5 months. Seven successive balance trials were conducted, three during the restriction period and four during the realimentation period. Each balance trial lasted three weeks. Between trials the animals were placed for one week in ground-floor pens bedded with sawdust to allow them more space and to reduce the risk of hoof problems. During the trials the animals were housed 
Table 1 Dry matter (DM), organic matter (OM), crude protein (CP), ash and gross energy (GE) content of the experimental feeds (DM basis)

\begin{tabular}{lcc}
\hline & Straw & Concentrate \\
\hline $\mathrm{DM}(\mathrm{g} / \mathrm{kg})$ & 875 & 869 \\
$\mathrm{OM}(\mathrm{g} / \mathrm{kg} \mathrm{DM})$ & 923 & 924 \\
$\mathrm{CP}(\mathrm{g} / \mathrm{kg} \mathrm{DM})$ & 46 & 173 \\
$\mathrm{Ash}(\mathrm{g} / \mathrm{kg} \mathrm{DM})$ & 77 & 76 \\
$\mathrm{GE}(\mathrm{MJ} / \mathrm{kg} \mathrm{DM})$ & 17.0 & 16.5 \\
\hline
\end{tabular}

Table 2 Ingredients of the concentrate in the diet $(\mathrm{g} / \mathrm{kg})$

\begin{tabular}{lc}
\hline Ingredients & $\mathrm{g} / \mathrm{kg}$ \\
\hline Sugar beet pulp & 870 \\
Potato protein & 100 \\
Mineral mixture (mervit 318)* & 30 \\
Total & 1000 \\
\hline * Vitamins A, D and trace elements, $\mathrm{NaH}_{2} \mathrm{PO}_{4} \cdot 2 \mathrm{H}_{2} \mathrm{O}, \mathrm{FeSO}_{4} \cdot 7 \mathrm{H}_{2} \mathrm{O}$ and $\mathrm{MgSO}_{4} .7 \mathrm{H}_{2} \mathrm{O}$.
\end{tabular}

individually in metabolism cages. Prior to the measurements the animals were allowed to adapt to the cages for a period of 11 days. This was followed by a 10-day collection period that consisted of three days in a metabolism cage and seven days in a respiration chamber. During each balance trial, feed refusal, faeces and urine were collected daily, and pooled, for each lamb and sampled. A small amount of $30 \%$ formalin was added to the faeces container for preservation. Before collection of urine, one litre of water acidified by 20 $\mathrm{mL}(6 \mathrm{~N}) \mathrm{HCL}$, was put in the collection bucket to prevent evaporation of ammonia and maintain the $\mathrm{pH}$ below 2 .

In each balance trial energy (EB) and nitrogen balances (NB) were assessed. All lambs were weighed once every two weeks. Apart from this live weight determination, the lambs were weighed on entering and leaving the chambers to obtain the live weight gain during the time when animals were in the respiration chambers. The amount of feed offered, was adjusted once every two weeks on the basis of metabolic weight. Daily feed intake for each lamb was recorded. The collected samples of feed, refusals and faeces were analyzed for $\mathrm{DM}$, ash, $\mathrm{N}$ and energy content. Urine was analyzed for $\mathrm{N}$ and energy content. Gross energy values of the feed, faeces and urine were determined using an adiabatic bomb calorimeter (model C7000 calorimeter; IKA Werke GmbH \& Co. KG, Staufen, Germany) according to ISO Standard 9831 (ISO, 1998).

The DM content of the feed offered, feed refusals and faeces were determined by drying representative sub-samples to a constant weight at $103^{\circ} \mathrm{C}$. Organic matter (OM) was calculated as weight loss of the same sub-samples during ashing at $550{ }^{\circ} \mathrm{C}$ for $3 \mathrm{~h}$. The $\mathrm{N}$ content of the feeds, refusals, faeces and urine were determined according to the Kjeldahl method (AOAC), 1995). Digestible energy (DE) and ME intake, and energy metabolizability (ME/GE) per lamb were determined from the energy content of feed consumed, and faeces, urine and methane excreted. Heat production (HP) of each lamb was determined daily from continuous measurements (every $3 \mathrm{~min}$ ) of $\mathrm{CO}_{2}, \mathrm{CH}_{4}$ and $\mathrm{O}_{2}$ exchange (Brouwer, 1965) in $24 \mathrm{~h}$ cycles. By subtracting the amounts of $\mathrm{N}$ in the feed residue, faeces, urine and ammonia in the air from the $\mathrm{N}$ in the feed, NB was calculated. From data on ME and HP, the EB per lamb was calculated (EB = ME - HP) (Brouwer, 1965). The quantity of protein and fat stored in the body can be estimated from the carbon and $\mathrm{N}$ balance. These were estimated in the experiment by using the respiration chamber in which the amounts of carbon and $\mathrm{N}$ entering and leaving the body were measured. The facilities of respiration chambers have been well 
described by Verstegen et al. (1987). From the EB and energy in protein (calculated as $23.7 \times 6.25 \times \mathrm{NB}$ ), the fat gain (g/day) was calculated as: ((EB - energy in protein)/39.8) (Brouwer, 1965). The mean energetic values of retained fat and protein were taken as $39.8 \mathrm{~kJ} / \mathrm{g}$ and $23.7 \mathrm{~kJ} / \mathrm{g}$, respectively (ARC, 1982). The value, 6.25 , was used for the conversion of $\mathrm{N}$ to protein.

According to the experimental block designs, comparisons were made within blocks by analyzing the observations of the restricted animals as deviations from the control animal in each block. In this way the block effects were removed from the data, and only the effects of restriction and realimentation were left. Because restriction and realimentation are events in time, the analysis concentrated on the effects in time. The following model was used:

$$
\mathrm{y}=\mathrm{a}_{0}+\Delta_{\mathrm{a} 0}+\left[\left(\mathrm{a}_{1}+\Delta_{\mathrm{a} 1}\right)-\left(\mathrm{a}_{0}+\Delta_{\mathrm{a} 0}\right)+\left(\mathrm{b}_{1}+\Delta_{\mathrm{b} 1}\right) \mathrm{t}_{\mathrm{r}}\right] \mathrm{s}
$$

In which:

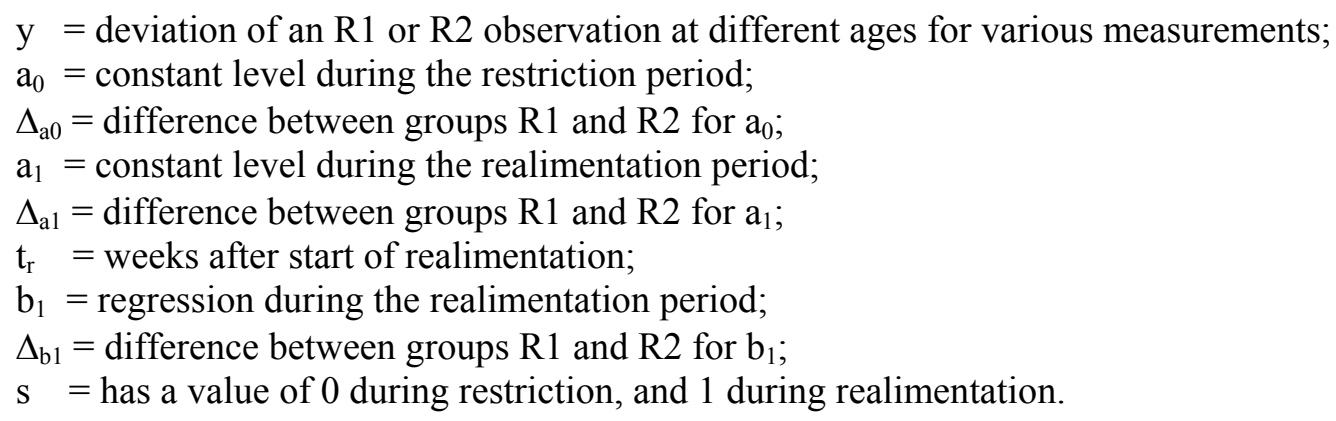

Parameters in Eq. [1] were tested in a step-wise manner, using the NLREG programme (Sherrod, 1992), by leaving out at each step non-significant $(\mathrm{P}>0.05)$ parameters. The final model therefore contained only parameters that differed significantly from zero.

\section{Results}

Means of live weight $(\mathrm{kg})$ and the values for the control animals based on metabolic weight for feed consumption, $\mathrm{N}$ intake, $\mathrm{N}$ losses in faeces and urine and $\mathrm{NB}$, the values based on $\mathrm{g}$ /day for daily weight, protein and fat gain, and the means based on $\mathrm{kJ} / \mathrm{kg}^{0.75} / \mathrm{d}$ for energy intake (GE, DE and ME), energy losses in faeces, urine and methane, and HP, EB and metabolizability (ME/GE) are presented in Table 3. These data are presented for different stages of the experiment. Equation [1] was fitted to the observations of the restricted animals as deviations from the control animal in each block. Estimates of the parameters for fitted curves are presented in Table 4. The relationship between NB and age during the whole experiment is presented in Figure 1. The means for restricted animals at the different stages of the experiment can be calculated by adding the estimates in Table 4 to the data of the control animals given in Table 3: For example, the estimated mean value for GE in the R1 animals at the onset of realimentation (at the age of 6.5 months) was $1056-308.9=747.1$, and at the end of the experiment (at the age of 14 months), $1043+56.8$ $=1099.8$. The GE of the control animals at the age of 6.5 and 14 months was 1056 and 1043, respectively. The estimated mean value for DE in R1 animals at the onset of realimentation was $642-333.6=308.4$, and at the end of experiment, $620+60=680$. The estimated mean value for ME in the R1 animals at the onset of realimentation was $544-296.4=247.6$ and at the end of experiment, $533+47.8=580.8$.

During the restriction period, restricted animals lost weight and showed a negative NB, whereas their low quality roughage intake increased $(\mathrm{P}<0.001)$ compared to that of the control (Table 4$)$. The energy intake of the restricted animals decreased $(\mathrm{P}<0.001)$ and $\mathrm{EB}$ became negative. The restricted animals lost protein and fat tissues, whereas the energy losses through faeces, urine, methane and heat decreased ( $\mathrm{P}<0.001)$ compared to the controls. The metabolizability of energy for the restricted animals was lower ( $\mathrm{P}<0.001$ ), and ME required for maintenance reduced to about $340 \mathrm{~kJ} / \mathrm{kg}^{0.75} / \mathrm{d}$, compared with about 480 $\mathrm{kJ} / \mathrm{kg}^{0.75} / \mathrm{d}$ for the controls (Figure 2). Increasing the duration of restriction from 3 to 4.5 months did not have a significant effect on metabolizability, NB, EB and the level of energy losses through methane, urine and heat. However, the amount of straw and GE $(\mathrm{P}<0.1)$ and ME intakes $(\mathrm{P}<0.08)$ of the R2 animals tended to be lower, compared to the R1 animals. 
During realimentation the $\mathrm{R} 1$ and $\mathrm{R} 2$ animals grew faster $(\mathrm{P}<0.001)$ than the control animals (Table 4). The realimented animals persisted in ingesting more $(\mathrm{P}<0.001)$ low quality roughage and showed consistently greater values for energy (GE, DE and ME) intake, $\mathrm{N}$ intake, metabolizability of energy, daily weight gain and protein and fat gain compared to the control animals. From the onset of realimentation until the end of the experiment the NB and EB of the realimented animals were higher $(\mathrm{P}<0.001)$ than those of the control animals, however, with negative slopes. In realimented animals, $\mathrm{N}$ and energy losses through faeces and urine were consistently lower $(\mathrm{P}<0.001)$, whereas energy loss through methane was consistently higher $(\mathrm{P}<0.001)$, although intakes were higher $(\mathrm{P}<0.001)$ compared to the control animals (Table 4$)$. The ME content of the diet was between 0.85 and 0.86 of the DE (Table 3 ).

Table 3 Means of live weight, feed and nitrogen intakes, nitrogen losses, nitrogen balance (NB), daily weight, protein and fat gain, intake of gross energy, digestibility of energy (ME/GE) in control (C) animals at different stages of the experiment

\begin{tabular}{|c|c|c|c|c|}
\hline & \multicolumn{4}{|c|}{ Age (months) } \\
\hline & $3.5^{\mathrm{a}}$ & $6.5^{\mathrm{b}}$ & $8^{\mathrm{c}}$ & $14^{\mathrm{d}}$ \\
\hline \multirow{2}{*}{\multicolumn{5}{|c|}{ Feed intake $\left(\mathrm{g} / \mathrm{kg}^{0.75} / \mathrm{d}\right)$ : }} \\
\hline & & & & \\
\hline Straw & 31.5 & 30.5 & 30.3 & 28.6 \\
\hline Concentrate & 35 & 35 & 35 & 35 \\
\hline \multirow{2}{*}{\multicolumn{5}{|c|}{$\mathrm{N}-$ losses $\left(\mathrm{g} / \mathrm{kg}^{0.75} / \mathrm{d}\right)$ : }} \\
\hline & & & & \\
\hline Faeces & 0.46 & 0.48 & 0.48 & 0.43 \\
\hline Urine & 0.32 & 0.33 & 0.32 & 0.34 \\
\hline 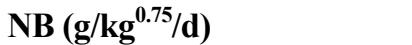 & 0.20 & 0.21 & 0.22 & 0.17 \\
\hline \multicolumn{5}{|l|}{$\operatorname{Gain}^{\dagger}$ (g/day) } \\
\hline Weight & 81.4 & 87.8 & 94.9 & 115.4 \\
\hline Protein & 18 & 23 & 26 & 27 \\
\hline Fat & 11 & 13 & 15 & 16 \\
\hline \multicolumn{5}{|l|}{ Energy intake $\left(\mathrm{kJ} / \mathrm{kg}^{0.75} / \mathrm{d}\right)$ : } \\
\hline Gross energy & 1028 & 1056 & 1078 & 1043 \\
\hline Digestible energy & 630 & 642 & 643 & 620 \\
\hline Metabolisable energy & 540 & 544 & 553 & 533 \\
\hline \multicolumn{5}{|l|}{ Energy losses $\left(\mathrm{kJ} / \mathrm{kg}^{0.75} / \mathrm{d}\right):$} \\
\hline HP & 476 & 483 & 502 & 483 \\
\hline Faeces & 398 & 414 & 435 & 423 \\
\hline Urine & 20 & 20 & 21 & 22 \\
\hline Methane & 70 & 78 & 69 & 65 \\
\hline $\mathrm{EB}\left(\mathrm{kJ} / \mathrm{kg}^{0.75} / \mathrm{d}\right)$ & 64 & 62 & 51 & 50 \\
\hline Metabolizability & 0.53 & 0.52 & 0.51 & 0.51 \\
\hline
\end{tabular}

a,b,c,d Ages at different stages of the experiment.

${ }^{\dagger}$ Measured daily gain when animals were in the respiration chambers.

The realimented animals had a lower $(\mathrm{P}<0.001) \mathrm{HP}$ at the initial stage of realimentation and increased at the later stages of the realimentation period (Table 4), and resulted in an increased maintenance energy requirement. At the initial stages of realimentation (first month) the maintenance energy requirement of restricted animals approaches the maintenance energy requirement of the control animals. The estimated parameter (Table 4) shows that increasing the duration of feed restriction did not have significant effects during compensatory gain. Although the $\mathrm{R} 2$ animals had higher $(\mathrm{P}<0.05)$ faecal $\mathrm{N}$ losses compared to the $\mathrm{R} 1$ animals, in general, they showed the same trends as the R1 animals. 
Table 4 Estimates and standard errors (s.e.) of the parameters for model [1], for the observations ${ }^{\mathrm{f}}$ of restricted animals as deviations from the control animals

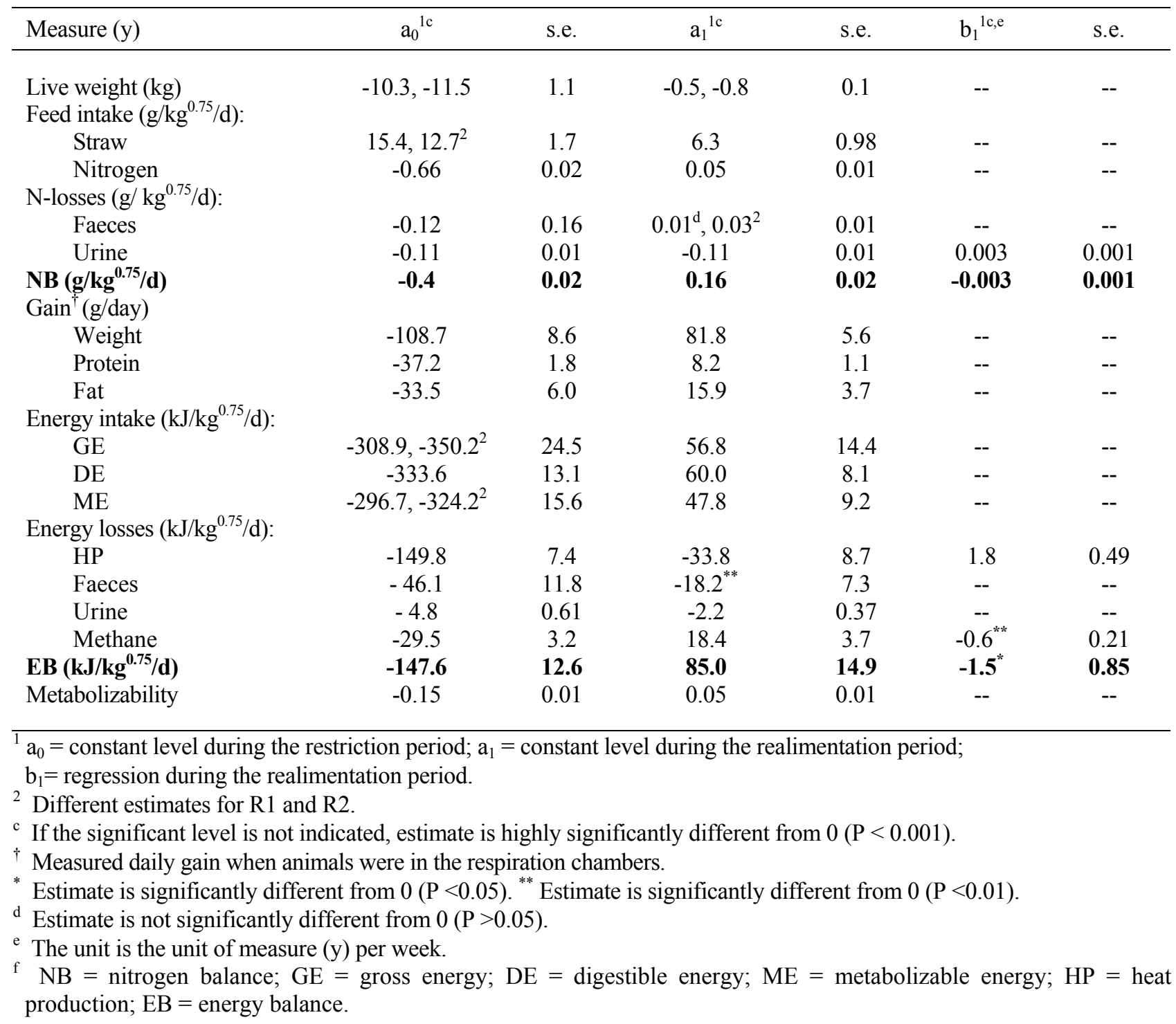

\section{Discussion}

Part of compensatory growth was caused by a sustained increase in fibrous feed intake. An increase in intake for realimented animals has been reported in other studies with sheep (Graham \& Searle, 1979). In the study of Butler-Hogg \& Tulloh (1982), in contrast, realimented sheep, after a period of feed quantity restriction, had significantly lower intakes than the controls for the first $10 \mathrm{~kg}$ of live weight gain. Ryan et al. (1993) also reported a lower intake during the first three months of realimentation for both sheep and cattle. These latter findings are not supported by the present results; most likely because a different type of feed restriction was imposed. They restricted animals by reducing the quantity of the offered feed. The present experiment showed that the higher intake of low quality roughage by realimented animals was related to the adaptation of these animals during restriction.

The results of this experiment showed that the ME required for maintenance in the control animals was about $480 \mathrm{~kJ} \mathrm{ME} / \mathrm{kg}^{0.75} / \mathrm{d}$. Graham \& Searle (1979) reported a value of $470 \mathrm{~kJ} \mathrm{ME} / \mathrm{kg}^{0.75} / \mathrm{d}$ for sheep, whereas the ARC (1980) suggested a range of $420-450 \mathrm{~kJ} \mathrm{ME} / \mathrm{kg}^{0.75} / \mathrm{d}$. These findings are not completely in line with our results, most likely because of a different method of estimation. Their results are based on the data of fasting heat production, whereas the observations of the present study are on sheep that were 


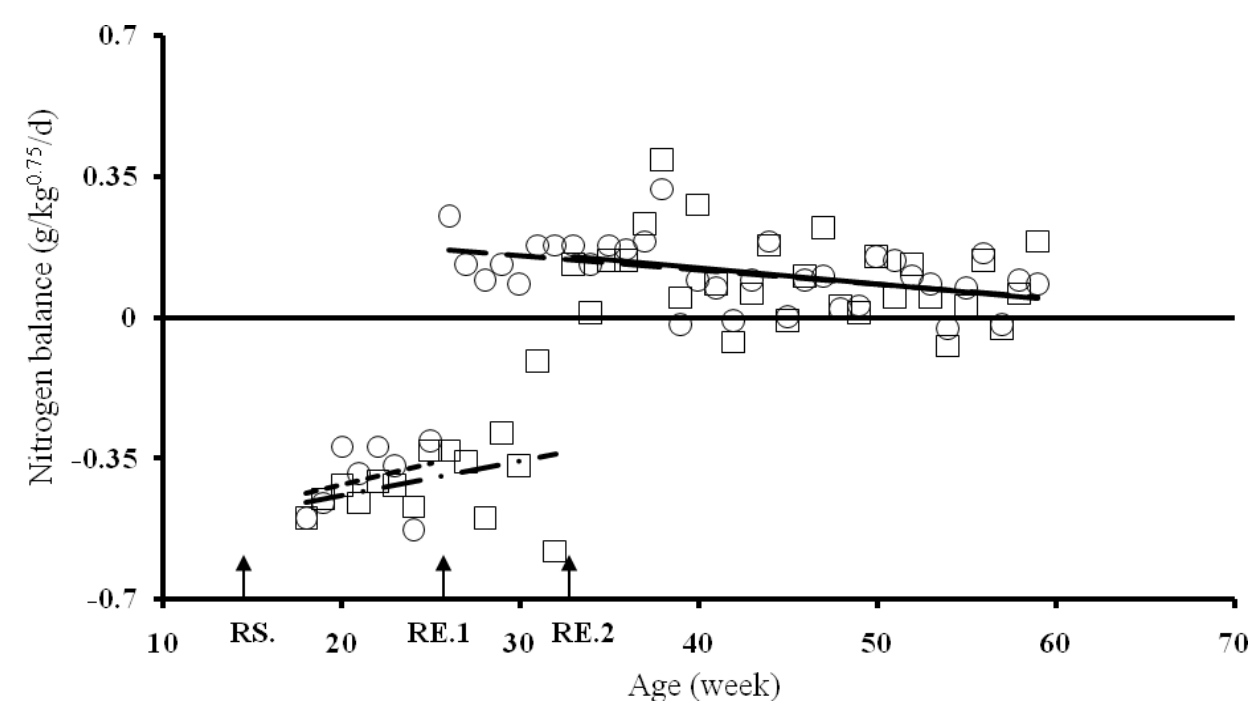

Figure 1 Differences for nitrogen balance (NB) of R1 and R2 animals with control animals from the start to the end of the experiment: (o) R1, and ( $\square$ ) R2; Regression lines: (-----), (- - - ) during restriction. (- - -), ( $(-)$ during realimentation; RS = age at the start of restriction periods; RE.1 and RE.2 = ages at the start of realimentation periods for R1 and R2 animals, respectively.

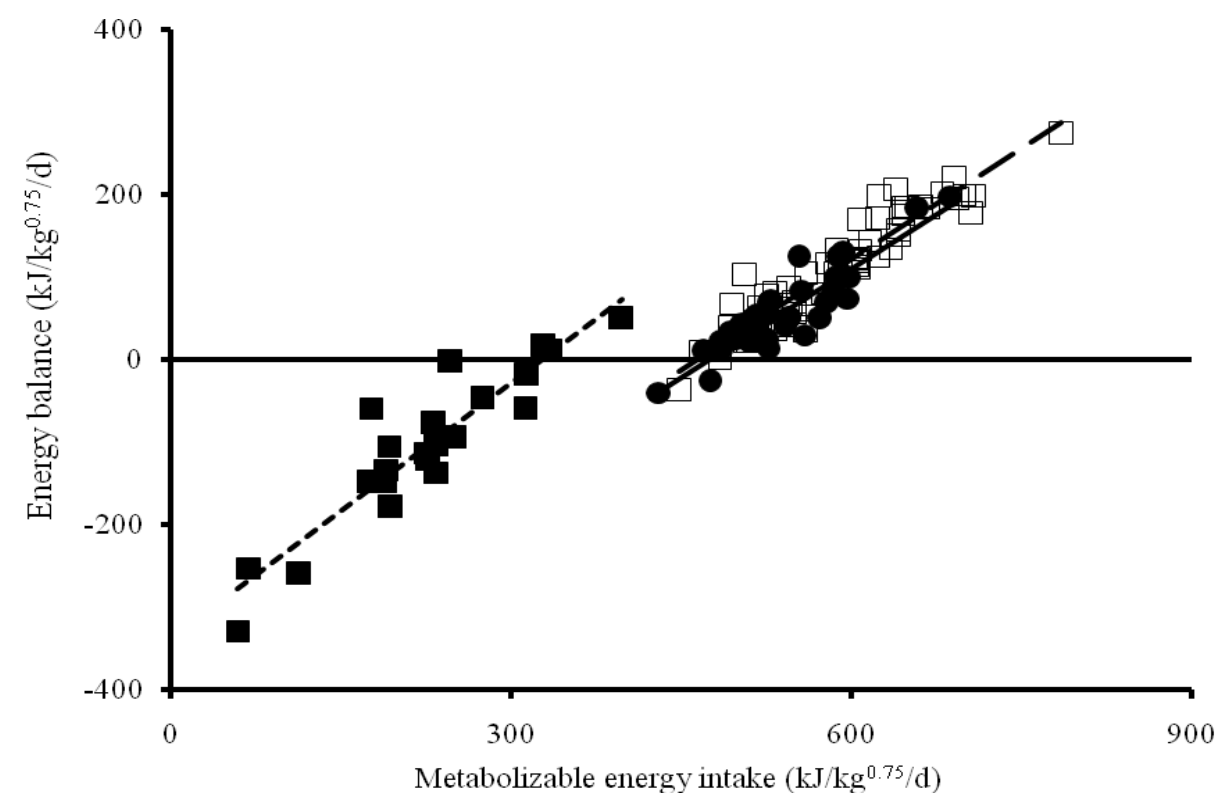

Figure 2 The relationship between energy balance (EB) and metabolizable energy (ME) intake: (a)

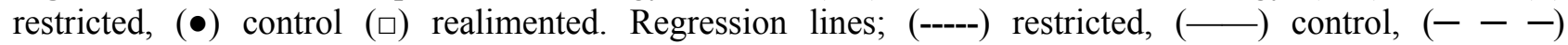
realimented.

restricted to maintain body weight at a constant level by feeding low quality roughage. However, they lost about $12 \%$ of their initial live weight by the end of the restriction period, although their low quality feed intake was about $50 \%$ higher than that of the controls (Table 4). During restriction, maintenance requirements of the restricted animals decreased by about $29 \%$ compared to the controls, amounting to 340 $\mathrm{kJ} \mathrm{ME} / \mathrm{kg}^{0.75} / \mathrm{d}$ (Figure 2). Graham \& Searle (1979) also reported a value of about $340 \mathrm{~kJ} \mathrm{ME} / \mathrm{kg}^{0.75} / \mathrm{d}$ for sheep when fed at zero energy retention. The increased HP of animals during later stages of the 
realimentation period points to an increased energy requirement for maintenance. However, they had a higher $(\mathrm{P}<0.001) \mathrm{ME}$ intake compared to the control animals (Table 4). This indicates that more energy was available for growth.

Our results show that after realimentation, metabolizability increased, implying an increased efficiency in ME utilization. The metabolizability values obtained in this experiment for the control and realimented animals corresponded well with the range (0.45 to 0.6) suggested by the ARC (1980) and Oosting et al. (1993) when sheep had ad libitum access to feed. Results in Table 3 suggest that metabolizability of the feed in the control animals reduced as they aged. In contrast, the metabolizability of the feed in the realimented animals at the same chronological age was higher $(\mathrm{P}<0.001)$ than in the controls (Table 4). This could be due to the delay in growth during restriction, and, therefore, at the time of realimentation these animals were in a younger physiological state than the control animals.

Nitrogen retention in the restricted sheep was negative (Table 4). Relative to metabolic weight, energy losses through faeces, methane and urine decreased in animals under restriction. This was probably caused by a low level of $\mathrm{N}$ intake and a decreased urinary $\mathrm{N}$ excretion in these animals. The sustained decrease in energy and $\mathrm{N}$ losses especially through urine and faeces during realimentation indicates that efficiency of feed utilization in realimented animals was higher than in the controls. This was probably caused by a physiological adaptation of R1 and R2 animals during restriction, which was maintained during realimentation.

During restriction, fat and protein gains of the R1 and R2 animals were negative. These animals used body tissues to obtain energy for survival, which obviously was not sufficient for maintenance, hence the body weight loss. The higher protein and fat gains of realimented animals was a reflection of depletion of these tissues during restriction. The R1 animals, after five months of realimentation, fully compensated and reached the same live weight as the control animals $(72.5$, s.e. $=1.94$ vs. 73.1 , s.e. $=2.47 ; \mathrm{n}=12)$. At the time this experiment was terminated (after six months realimentation for the R2 animals) the R2 animals did not fully compensate. The R2 animals did not have a higher intake and gain than the R1 animals during realimentaion. Because of a longer period of restriction, it seems as if they needed a longer period of realimentation to reach the same live weight as the control and R1 animals. This finding does not confirm the data of Graham \& Searle (1979), who reported a consistently higher growth rate when sheep were maintained at the same live weight for six months compared to sheep that were maintained for four months.

Metabolizable energy was between 0.85 and 0.86 of the DE (Table 3). These values are above the generalized value of 0.82, suggested by Blaxter (1962) and the ARC (1965). However, Gingins (1978) and Koenig et al. (1980) reported similar results. This might have been due in part to the type of diet, increased energy density of the diet and low methane and urinary $\mathrm{N}$ losses. Thomson et al. (1982) also found that the ME content of pelleted diets fed to lambs at live weights of 30 to $50 \mathrm{~kg}$ was between 0.86 and 0.93 of the $\mathrm{DE}$, which was attributed to low methane and urinary $\mathrm{N}$ losses.

The expression of compensatory growth can be explained partially by the increased ME intake. The present study shows that the increased ME intake is related to a distinctly higher low quality roughage intake during restriction, which forms the foundation of a sustained increased low quality roughage intake, during realimentation. A small part of the compensatory growth is caused by lower energy maintenance requirements of realimented animals. The improved metabolizability of energy and sustained lower losses of $\mathrm{N}$ and energy indicate that realimented animals utilize their feed more efficiently than the controls, which can probably be attributed to an improved digestibility of the low quality feed OM intake. Consistently higher methane production through the realimentation period possibly relates to a consistently higher intake of low quality feed. Ruminants on low quality feeds normally produce more methane (Leng, 1993) than when on high quality feed. Extending the period of restriction (more than three months) caused lower growth rate in immature sheep, which is not advisable.

\section{Conclusions}

Production systems of small ruminants in most parts of the world, particularly in developing countries, depend mainly on natural vegetation of range- and farmlands. Seasonal variations in feed quantity and quality cause periods of live weight loss and gain in grazing animals. The availability of supplements is low and they often have to be purchased at high prices. When integrating the effect of compensatory growth into feeding strategies, the efficiency of the available feeds is increased. 


\section{References}

Andersen, B.B., 1980. Feeding trials describing net requirements for maintenance as dependent on weight, feeding level, sex and genotype. Ann. Zootech. 29, 85-92.

AOAC, 1995. Official Methods of Analysis. (15 $5^{\text {th }}$ ed.). Association of Official Analytical Chemist, Washington, D.C., USA.

ARC, 1965. The Nutrient Requirements of Farm Livestock. No. 2. Ruminants, London, UK.

ARC, 1980. The Nutrient Requirements of Ruminant Livestock. Commonwealth Agricultural Bureaux, Farnham Royal, England.

Blaxter, K.L., 1962. The Energy Metabolism of Ruminants. Hutchinson, London, England.

Brouwer, E., 1965. Report of sub-committee on constants and factors. In: Energy Metabolism. Ed. Blaxter, K.L., Eur. Assoc. Anim. Prod. Publ. No. 11. Academic Press, London, England. p. 441.

Butler-Hogg, B.W. \& Tulloh, N.M., 1982. Growth patterns in sheep: the effects of weight losses on compensatory growth and feed intake in Corriedale sheep. J. Agric. Sci., Camb. 99, 641-649.

Drew, K.R. \& Reid, J.T., 1975. Compensatory growth in immature sheep. III. Feed utilization by sheep subjected to feed deprivation followed by realimentation. J. Agric. Sci., Camb. 85, 215-220.

Ferrell, C.L., Koong, L.J. \& Nienaber, J.A., 1986. Effects of previous nutrition on body composition and maintenance energy costs of growing animals. Br. J. Nutr. 56, 595-605.

Flatt, W.G. \& Coppock, C.E., 1963. Fasting metabolism of dry, nonpregnant adult dairy cows. J. Dairy Sci. 46, 638 (Abstr.).

Foot, J.Z. \& Tulloh, N.M., 1977. Effects of two paths of live weight change on the efficiency of feed use and on body composition of Angus steers. J. Agric. Sci., Camb. 88, 135-142.

Gingins, M., 1978. The efficiency of the body weight loss-regain process in the adult ruminant. $\mathrm{PhD}$ thesis No. 6228 ETH Zürich. (In French with English summary).

Graham, N.McC. \& Searle, T.W., 1972. Growth in sheep. II. Efficiency of energy and nitrogen utilization from birth to 2 years. J. Agric. Sci., Camb. 79, 383-389.

Graham, N.McC. \& Searle, T.W., 1979. Studies of weaned lambs before, during and after a period of weight loss. I. Energy and nitrogen utilization. Aust. J. Agric. Res. 30, 513-523.

Graham, N.McC., Searle, T.W. \& Griffiths, D.A., 1974. Basal metabolic rate in lambs and young sheep. Aust. J. Agric. Res. 25, 957-971.

Gray, R. \& McCracken, K.J., 1979. Plane of nutrition and the maintenance requirement. In: Energy Metabolism of Farm Animals. Proc. 8th Symp., Eur. Assoc. Anim. Prod. Publ. 26. pp. 163-167.

ISO, 1998. Animal feeding stuffs, animal products, and faeces or urine. Determination of gross calorific value. IS. 9831. International Organization for Standardization, Geneva, Switzerland.

Hoch, T., Jurie, C., Pradel, P., Cassar-Malek, I., Jailler, R., Picard, B. \& Gabriel, J., 2005. Effects of hay quality on intake, growth path, body composition and muscle characteristics of Salers heifers. INRA. EDP Sciences, 2005. Anim. Res. 54, 241-257.

Hogg, B.W., 1977. Effects of growth patterns on body composition and compensatory growth in sheep. $\mathrm{PhD}$ thesis, University of Melbourne, Australia.

Kamalzadeh, A., 2005. Modelling the productivity of a breeding sheep flock for different production systems. Asian-Aust. J. Anim. Sci. 18, 606-612.

Kamalzadeh, A., Van Bruchem, J., Koops, W.J., Tamminga, S. \& Zwart, D., 1997. Feed quality restriction and compensatory growth in growing sheep: feed intake, digestion, nitrogen balance and modeling changes in feed efficiency. Livest. Prod. Sci. 52, 209-217.

Koenig, J.M., Boling, A. \& Bull, L.S., 1980. Energy and protein metabolism in ewes as influenced by age and dietary protein-calorie ratio. J. Anim. Sci. 51, 1011-1022.

Ledger, H.P. \& Sayers, A.R., 1977. The utilization of dietary energy by steers during periods of restricted food intake and subsequent realimentation. 1. The effect of time on the maintenance requirements of steers held at constant live weights. J. Agric. Sci., Camb. 88, 11-26.

Leng, R.A., 1993. Quantitative ruminant nutrition - A green science. Aust. J. Agric. Res. 44, 363-380.

Oosting, S.J., Boekholt, H.A., Los, M.J.N. \& Leffering, C.P., 1993. Intake and utilization of energy from ammonia-treated and untreated wheat straw by steers and wetter sheep given a basal diet of grass pellets and hay. Anim. Prod. 57, 227-237.

Ryan, W.J., Williams, I.H. \& Moir, R.I., 1993. Compensatory growth in sheep and cattle. 1. Growth pattern and feed intake. Aust. J. Agric. Res. 44, 1609-1621. 
Sherrod, P.H., 1992. Nonlinear Regression Analysis Program (NLREG). Version 1.8. Nashville, T.N., USA. pp. 1-34.

Thomson, E.F., Bickel, H. \& Schürch, A., 1982. Growth performance and metabolic changes in lambs and steers after mild nutritional restriction. J. Agric. Sci., Camb. 98, 183-194.

Verstegen, M.W.A. \& Henken, A.M., 1987. The Wageningen respiration unit for animal production research: A description of the equipment and its possibilities. In: Energy Metabolism in Farm Animals. Eds Verstegen, M.W.A. \& Henken, A.M., Dordrecht, The Netherlands: Martinus Nijhoff. p. 478.

Verstegen, M.W.A., Van der Hel, W., Brandsma, H.A., Henken, A.M. \& Bransen, A.M., 1987. The Wageningen respiration unit for animal production research; a description of the equipment and its possibilities. In: Energy Metabolism in Farm Animals. Effects of Housing, Stress and Disease. Eds Verstegen, M.W.A. \& Henken, A.M., Dordrecht, The Netherlands: Martinus Nijhoff. pp. 21-48.

Walker, J.J. \& Garrett, W.N., 1970. Shifts in the energy metabolism of male rats during their adaptation to prolonged undernutrition and during their subsequent realimentation. In: Energy Metabolism of Farm Animals. Proc. 5th Symp., Eur. Assoc. Anim. Prod. Publ. 13. pp. 193-196.

Webster, A.J.F., Smith, J.S. \& Mollison, G.S., 1982. Energy requirements of growing cattle: effects of sire breed, plane of nutrition, sex and season on predicted basal metabolism. In: Energy Metabolism of Farm Animals. Proc. 9th Symp., Eur. Assoc. Anim. Prod. Publ. 29. pp. 84-87.

Winter, W.H., Tulloh, N.M. \& Murray, D.M., 1976. The effect of compensatory growth in sheep on empty body weight, carcass weight and the weights of some offals. J. Agric. Sci., Camb. 87, 433-441. 